\title{
A NEW APPROACH IN TEACHING INTERIOR DESIGN STUDIO AT THE AHLIA UNIVERSITY
}

\author{
Dr. Imad Assali \\ Associate Professor / Chairperson of Interior Design Department, \\ Ahlia University, The Kingdom of Bahrain
}

\begin{abstract}
The turn of the twenty-first century is witnessed extremely fast changes occurring in the interior design profession outside the traditional disciplinary boundaries by the dominance of information technologies that invites more complex design problems resulting in new design methodologies. Therefore, interior design is experimenting with significant changes outside the traditional disciplinary boundaries, where new terms, concepts, and vocabulary emerged replacing simplicity and clarity. Paradoxically, interior design graduates struggle to shift successfully from academic study to the interior design professional practice as they are not used on collaborative work in their study which is the nature of the interior design practice. Responding to these challenges needs to develop a design studio paradigm to improve our programs and the quality of education by creating curricula, syllabi, and teaching materials encouraging an inventive and collaborative design work that enable interior design students to develop the skills needed for their future professional practice. According to the Professional Relations Directorate at Ahlia University, career opportunities for interior design students were looking relatively negative, 62.96\% of interior design graduates in 2018 were unemployed. Accordingly, this research describes and evaluate the vertical studio approach which allows students from various levels and skills to collaborate on a design project to create an innovative design that prepares them to the changing needs in the market for the 21 st century, it is also believed that this model will be relevant to all design disciplines. The findings of this research show that vertical design studio has a strong potential in the high quality of the students' design projects and recommends applying this paradigm in the interior design department at Ahlia University and other design schools in Bahrain.
\end{abstract}

Keywords: Interior Design Education, vertical Design Studio, teamwork, curriculum, collaborative studio, Design Pedagogy

Cite this Article: Imad Assali, A New Approach in Teaching Interior Design Studio at the Ahlia University, International Journal of Civil Engineering and Technology (IJCIET), 12(2), 2021, pp. 11-18.

https://iaeme.com/Home/issue/IJCIET?Volume=12\&Issue=2 


\section{INTRODUCTION AND BACKGROUND}

"The only sure sign of life is growth, and the only sure sign of growth is change. [Bachman, 2009. pp:01]

Design as an agent of change has value in all aspects of society, it delivers services that can be applied to solve any problem and develop professional skills for careers in the industry. As the advancement of technology nowadays is changing all aspects of life, therefore, design education needs to adapt its structure to prepare graduates to meet today's challenges in professional practices (Kolhe (2017); Liem (2010); Shahi et al. (2013)). Valtonen (2016) claimed that universities nowadays still educating students in similar ways for almost a century. Pilling \& Nicol (2000) added design education nowadays prepares graduates that are no longer in harmony with the evolving professional practice. Among different attempts to revise and develop design studio teaching and practice to meet the needs of professional practices by scholars, I noted: Ashraf Salama (1995) and Ashraf Salama \& Nicholas Wilkinson. ed. (2007) analyzed the traditional studio pedagogy; Andrea Liem (2010) outlines the implementation of vertical learning within a studio environment in conjunction with systems design; Derya Adigüzel Özbek; Armağan Seçil Melikoğlu Eke; Ebru Yücesan; and Betül Ozar (2018) explores the vertical interior design studio in relation to contemporary approaches.

Therefore, interior design education requires transformation from the current practice toward innovative practice especially design studio which should be developed and tailored to encourage students to strive for innovation to cope with nowadays technological advancement.

\subsection{Interior Design Graduates Attributes in Bahrain}

Different bodies in Bahrain such as the Higher Education Council (HEC) and the Bahrain Quality Assurance (BQA) urged the higher education institutions to prepare their graduates with the skills and abilities employers are looking for to start their career effectively. In 2019 the Centre for Measurement \& Evaluation (CME) at Ahlia University did a survey of the interior design employers in Bahrain to check their satisfaction with the interior design graduates. The most common finding from the survey was that employers and organizations need graduates to have both technical and creative skills to successfully participate in a contemporary work environment (Grieve \& Meek, 2015). As reported by Louisea \& Fiona (2017), employers have continued complaints about lacking design graduates of interpersonal and communication skills. Moreover, Reid \& Sabet (n.d) reported that graduates of interior design lack communication skills, analytical thinking and problem solving, business skills, teamwork skills, and software skills. Learning approach as cited by Louisea \& Fiona (2017. pp:1655) "Using formalised peer learning purposefully in studio is a way to strengthen the development of graduate attributes that industry has been calling for, for over the last two decades. Being able to communicate, work in teams, solve problems, use technology, as well as show initiative, be enterprising and manage self are most often recognized as critical to successful employment. Such attributes extend beyond disciplinary content, positioning graduates to engage in work futures that are increasingly globalized, diverse and complex".

In addition, alumni survey in 2019 by (CME) revealed that $56.8 \%$ of the graduates from interior design at Ahlia University lack the technical and business skills required by employers. Clearly a new initiative in interior design curricula in design schools must have a balance of technical, theoretical and practical skills to prepare students for full integration into the business of design (Reid \& Sabet, n.d). Different scholars like (Gentes et al. (2016); Spiridonidis \& Voyatzaki (2007) assured that studio teaching must equip students with the necessary skills to be competitive in business. In order to achieve this, Alkhalidi (2016) argues that graduates should be adapt to innovation; proactively respond to changing environments; and interact with the global level. 
The question arises here is "how the interior design department at Ahlia University prepares its students with the employability skills to face the changing demands of the interior design profession?". A collaborative design studio is the best scenario where students from different grade levels with varying experience almost identical to a work environment. Saxena \& Saxena (2013) argued that when students graduated and join the job market, they need to work with multinational and multidisciplinary teams to deliver business. Therefore, preparing them in their undergraduate study to such experience make it easy for them to use their acquired skills in a collaborative and multidisciplinary environment.

\subsection{Design Studio Education}

The studio model in most design schools was originated from the French Ecole de Beaux Art and the German Bauhaus schools which main aim focuses on problem-solving exercises with little attention for socio-cultural issues (Robinson (2013); Salama (1995). Arguably, after the World War II, design education moved to the United States universities where students from around the globe joined these three universities and facilitated the spread of architectural education all over the world.

A design studio like most design programs worldwide has a privileged position in design education that constitute more than $50 \%$ of the curriculum with the highest credit hours compared to theoretical courses (Ibrahim \&Utaberta (2011); Masri (2017); Thompson, 2002). As cited by Doyle et al. (2015). Pp:3) "The pedagogical core of the design studio is the 'desk crit', a collaborative activity where the teacher and the student do design work together, discussing and sketching possibilities and imagining the consequences of design choices. During desk crit interactions the design teacher works to understand what the student is trying to do with his or her design work, provides feedback on these ideas and works with the student to further develop them". In addition, Robinson (2013. pp:08) summarized the studio model: "the studio model is the crown jewel of design education" influence individuals and society in an innovative way to provide beneficial outcomes. Arguably, architects and interior designers nowadays no longer work on their own, but in teams in collaboration with others. Unlike the traditional teaching classroom, the design studio is a reflective social environment encourage collaboration that act as stimulants to learning (McClean \& Hourigan, 2013). Concurrently, Emam et al. (2018) point out that the complexities of nowadays professional practice in design require collaborative teamwork rather than the simplicity of traditional studios that depend heavily on individuality and personal-biased practice. With this traditional model, most students have limited interaction with real clients, hindering professional development. Furthermore, it is believed that the articulation of design ideas occurs through collaboration and communication with others (Özbek et al. (2018); Salama \& Wilkinson (2007); Kamalipour et al., 2014). This finding was later confirmed by Kamalipour et al. (2014) who argued that the design process will improve efficiently due to debate, collaboration, and discussion with others to deal with the complexity of design problems. Interestingly, from my experience as an academic and studio educator, the paradigm of design studio education in most design schools focus on a common dominance of individuality in design practices. Accordingly, the actual setting of a design studio in design programs should crucially depend on collaborative pedagogy. Having this in mind, design studios must renew themselves and students' tendency in design process should be in collaboration with other peers in pursuing their projects rather than working in isolation from others. The survey by Ismail \& Soliman (2010) at King Abdul-Aziz University, explained the value of vertical design studios over the traditional design studio where student's interaction from different grade levels (sophomores, juniors, and seniors) promote deep learning. Thus, the transformation of a traditional Design studio which does not deal with the practical realities of contemporary societies to an interdisciplinary studio approach deals with 
the advances in computers and telecommunication technologies will present a good opportunity for a good design studio practice.

\subsection{Advantages of Vertical Design Studio}

Different scholars like (Ismail \& Soliman (2010); Reid \& Sabet (n.d); Özbek et al. (2018); Barnes (1993); and Salamah, 1995) reported the advantages of teamwork in the vertical design studio are numerous include:

- Vertical design studio leads to more creativity in design project as each student brings new ideas to solving a design problem (Ismail \& Soliman).

- Teamwork in the vertical studio leads to more critical thinking and analysis as each student brings a different idea.

- Teamwork in the vertical studio can produce the design work faster than individual work.

- Teamwork learning in the vertical studio leads to exchanging more knowledge about the design project subject.

\section{CONTEXT AND SCOPE OF RESEARCH}

"To remain silent about the values represented in what we do, either out of mistaken belief that professionals must remain ethically neutral or out of a romantic dismissal of all normative values, is to eliminate one of the main reasons for the profession's very existence." (Salama \& Crosbie, 2010.pp: 10).

In reviewing the interior design curriculum in most of the universities, the current method of teaching design studios is still following the old rules and principles that put distance from the real-world and miss the opportunity to learn from nowadays technological developments. The method of a traditional design studio is a teacher-centered approach where the studio instructor is the only source of knowledge by providing a design project brief for students, and students individually work on the design process to submit the project which finally presents it in front of an expert audience.

Emam et al. (2018) and Mcpeek (2009) argued that this method reduces the level of productivity as it depends on the trial and error process where students are guided to solve a defined problem in a design project. Whereas the interior and architectural design are a collaborative process in professional practice which include the interaction of architects, designers, engineers, technical staff and client. Therefore, the vertical design studio, which is a learner-centered approach is the best scenario in design education which emphasizes interaction, and teamwork which simulate design professional practice (Liem (2010); Louisea \& Fiona (2017); Thompson, 2002). Incorporate students of differing levels as a unified team support student learning experience and establish a varied collection of experiences related to problem-solving, innovation, creativity, competition, sharing ideas, expertise, communication, evaluation, and critique into the studio environment (Kamalipour et al. 2014; Peterson \& Tober, 2017). As cited by Corazzo (2015. Pp: 12) "The difference between design education today and design education over the past century is that designers must now strategize the tools they shape [w] here design once relied on craft guild traditions functioning in slow evolutionary patterns based on common sense, trial-and-error and experience, we now use models, simulations, decision theory and systems thinking in the post-industrial age." In addition, the vertical design studio described "Although senior students have more fully developed technical skills and a broader knowledge of professional design issues, their younger colleagues have an enthusiasm and fresher outlook that is continually stimulating and challenging. The combination of these two peer groups creates a very meaningful and interactive experience" (Doyle et al. (2015. pp: $3)$. 
Arguably, traditional design pedagogy concentrates more on practical parts rather than theoretical one, the collaborative experiences in design studios, on the contrary, can cover the intersection of practical and theoretical knowledge and stimulate students to devote more activity and participation (Kamalipour et al. 2014). Moreover, a study by Ismail \& Soliman (2010), demonstrated that collaboration among students in their work has a positive effect on educational gains and students' outcomes. They added group achievement on a design project is more than individuals working alone. This process reflects the reality of a professional practice that depends on group work. In collaborative design studio students are introduced to the notion that the "whole is greater than the sum of its parts" [Aristotle] (as cited in Reid \& Sabet, n.d). Özbek et al. (2018) argued each student has different knowledge to a design problem, therefore producing a project with agreements and disagreements will provide richness and diversity to the final design project, it also fosters success in developing a wider range of graduate attributes. Different universities such as the Rhode Island School of Design and the University of Bedfordshire used the vertical studio model in design programs like architecture, interior design, and industrial design to expose students to contextual thinking techniques (Peterson\& Tober, 2017). Valtonen (2016) argued that design programs are quite different from other disciplines where designers should be educated to produce innovative solutions where traditional design processes unable to deal with the complexity of nowadays problems. Barnes (1993) discussed that students from the lower levels are skilled and savvy and can be very stimulating to upper levels students. He suggested that different peer groups will accelerate student performance and experiences than in a traditional studio and faculty feel more creative.

\section{STRUCTURING THE VERTICAL DESIGN STUDIO}

"Collaborative learning is a pedagogy that has at its center the assumption that people make meaning together and that the process enriches and enlarges them".

(cited by Mcpeek, 2009. pp:34).

The vertical design studio can be applied in different design disciplines where students across various levels and experiences (levels 2 and 3 ) collaborate on a design project to solve a complex design problem using different methodologies and teamwork (Mcpeek, 2009). Betz, 2004 \& Delgado, 2010) argue that a first-year design studio as an introductory course that develops students' design language- including manual and digital representation, research and writing will not be part of a vertical design concept as it is too advanced for this introductory course. Conversely, Emam et al. (2018) stated that one of the common problems in teamwork is a free ridder problem when one member insignificant contributes to group work. Another challenges in the vertical studio is student's evaluation. As cited by (Mcpeek \& Dockter, 2008. pp.89) "individual grades provide a mechanism to ensure individual accountability, but they may minimize the importance of the group effort... Group grades ensure that the group is held accountable and that all members support each other's learning, but if individuals are not held accountable, group grades create opportunities for ,easy riders " to avoid responsibility”. In addition, Mcpeek (2009) and Emam et al. (2018) suggested a holistic assessment approach to be conducted for individuals and the group as follows:

- Peer assessment: each student in the group evaluates the other members, which in turn helps the studio educator to check who is working and who is not.

- Each student evaluates himself in a reflective manner.

- Group assessment: is based on a jury, where each student evaluates all the students depending on the quality of work presented. 
- Studio Educator assessment: the studio educator evaluates the entire students based on his observation and discussion in the studio.

\section{CONCLUSION}

The emergence of new technology in the 21 st century has influenced all aspects of life, encouraging interior design education to change. Therefore, in order to keep pace with this technological advancement, a new model for teaching design studios must appear to produce the desired quality of graduates with the needed learning experiences to be relevant in the $21 \mathrm{st}$ century (Teixeira, 2005). As interior design graduates must communicate with engineers, architects, landscape designers, and urban designers, vertical design studio will improve student's communication skills. Moreover, different scholars have addressed that facing the challenges in the design profession practice nowadays needs teamwork interaction. Accordingly, the concept of the vertical studio is a good example for improving interior design education which fosters communication, teamwork, creativity, and innovation compared to the traditional studio. Finally, it is noteworthy that vertical design studio - a learner-centered approach- is an effective one to promote increased professional skills and lessened critiques by the design professions about intern practitioners.

\section{ACKNOWLEDGEMENT}

This research is supported by Ahlia University.

\section{REFERENCES}

[1] Bachman L. (2009). "Affecting Change in Architectural Education". ARCC JOURNAL. VOLUME 6 ISSUE 1 Available online: https://www.researchgate.net/publication/277582385 Affecting Change in Architectural Education

[2] Kolhe N. (2017). "Innovative Tools and Techniques to Teach Architecture". International Journal of Engineering Research and Technology. ISSN 0974-3154 Volume 10, Number 1. Available online: http://www.irphouse.com

[3] Liem A. (2010). "Planning and Early Implementation of Vertical Studio Teaching based on a Systems Design Approach". International Conference on Engineering and Product Design Education 2 \& 3 September 2010, Norwegian University of Science and Technology, Trondheim, Norway.

[4] Shahi S.; Doehler S.; Vogel C. (2013). "Business Sensible Design Education". Designing Design Education for India. 13th March to 15th March , 2013- Indian Design Council.

[5] Valtonen A. (2016). "Designing Universities of the Future". 2016 Design Research Society. 50th Anniversary Conference. Brighton. UK. P: 141.

[6] Pilling S. \& Nicol D. edit. (2000). "Changing Architectural Education Towards a new professionalism”. London and New York. Published by Spon Press. ISBN 0-203-99234-2.

[7] Grieve F. \& Meek K. (2015). "Whose Job Is It Anyway?". Proceedings of the 3rd International Conference for Design Education Researchers. 28-30 June 2015, Chicago, Il, USA. Volume 1.

[8] Louisea M. \& Fiona P.J. (2017). "Evolving pedagogy: is studio a state of mind?". Conference proceedings of the Design Management 7-9 June 2017. Academy Research Perspectives on Creative Intersections. Vol. 5. Hong Kong. 
[9] Reid R. \& Sabet M. (n.d). "Collaboration and Mentoring: Critical thinking and leadership in design education, Preliminary Observations of a Case Study in Process". Available online: https://www.academia.edu/19996601/COLLABORATION_AND_MENTORING

[10] Gentesa A., Renonb A., Bobroff J. (2016). "Design and Interdisciplinarity: the improbable introduction of "fundamental physics" in a design school". 2016 Design Research Society. 50th Anniversary Conference. Brighton. UK. P: 171.

[11] Spiridonidis C. \& Voyatzaki M. (2007). "Teaching and Experimenting with Architectural Design: Advances in Technology and Changes in Pedagogy". Transactions on Architectural Education No $35 . \quad$ Available online: http://www.eaae.be/wpcontent/uploads/2017/04/35_teaching-and-experimenting-with-architectural-design.pdf

[12] Alkhalidi A S. (2016). "Future Directions in Interior Design Education". ICIRS Conferences. Journal of leadership and international development. ISSN 2377-9691

[13] Saxena R. \& Saxena R. M. (2013). “A Collaborative \& Multi-Disciplinary Learning Experience for Design and Social Innovation”. Designing Design Education for India. 13th March to 15th March 2013- Indian Design Council.

[14] Robinson L. B. (2013). "Situated Studio: Cultivating Social Responsibility in Interior Design Education". A first-year paper submitted in partial satisfaction of the requirements for the degree Doctor of Education in Teaching and Learning (Curriculum Design). University of California, San Diego

[15] Salama, A. (1995). New trends in architectural education: Designing the design studio. United Kingdom: ARTI-ARCH.

[16] Ibrahim N. L. N. \& Utaberta N. (2011). "Learning in Architecture Design Studio". UKM Teaching and Learning Congress 2011. Procedia - Social and Behavioral Sciences 60 (2012) 30 -35 . Available online at www.sciencedirect.com

[17] Masri S. S. (2017). "Improving Architectural Pedagogy toward Better Archistructural Design Values". Athens Journal of Architecture - Volume 3, Issue 2 - Pages 117-136. Available online: https://doi.org/10.30958/aja.3-2-1 doi=10.30958/aja.3-2-1

[18] Thompson B. E. (2002). “Studio Pedagogy for Engineering Design”. Int. J. Engng Ed. Vol. 18, No. 1, pp. 39-49, 2002. TEMPUS Publications.

[19] Doyle M.; Flanagan R.; Moustafellos J. (2015). "Learning by Doing: Studio Classes in MIS Education". Twenty First Americas Conference on Information Systems, Puerto Rico. Available online:

https://pdfs.semanticscholar.org/1c6e/fe1abd12dc7fe795aefd2ff027fafc0122d9.pdf?_ga=2.596 99752.407665150.1579839203-371983187.1573097117

[20] McClean D. \& Hourigan N. (2013). "Critical Dialogue in Architecture Studio: Peer Interaction and Feedback". Journal for Education in the Built Environment, 8:1, 35-57, DOI: 10.11120/jebe.2013.00004. Available online: https://doi.org/10.11120/jebe.2013.00004

[21] Emam M.; Taha D.; ElSayad Z. (2018). "Collaborative pedagogy in architectural design studio: A case study in applying collaborative design". Alexandria Engineering Journal. Available Online: www.elsevier.com/locate/aej 
[22] Özbek D. A.; Eke A.S.M.; Yücesan E.; Ozar B. (2018). "Vertical Design Studio Experience in Interior Architecture Education". Online Journal of Art and Design. volume 6, issue 2, April 2018.

[23] Salama A. \& Wilkinson N. (2007). "Design Studio Pedagogy: Horizons for the Future". The Urban International Press. Gateshead, The United Kingdom.

[24] Kamalipour H.; Kermani Z. M.; Houshmandipanah E. (2014). "Collaborative Design Studio on Trial: A Conceptual Framework in Practice: Current Urban Studies, Published Online in SciRes. http://www.scirp.org/journal/cus

[25] Ismail A. M. \& Soliman M. H. (2010). "Integrating Multi-Grade Collaborative Learning Pedagogy into Design Studios". Special Volume: Design Education: Explorations and Prospects for a Better Built Environment. Volume 4 - Issues 2-3 - July and November 2010.

[26] Barnes J. (1993). “A Case for the Vertical Studio". Journal of Interior Design. Wiley Online Library. Available online: https://doi.org/10.1111/j.1939-1668.1993.tb00150.x

[27] Salama A. M. \& Crosbie M. J. (2010). "Design Education: linearrations and Prospects for a Better Built Environment". Architecture Planning Built Environment Studies. International Journal of Architectural Research. Volume (4) - Issues (2-3) - July-November 2010.

[28] Mcpeek K. T. (2009). "Collaborative Design Pedagogy: A Naturalistic Inquiry of Architectural Education". Ph. D Dissertation. Texas A\&M University. Available online: http://oaktrust.library.tamu.edu/bitstream/handle/1969.1/ETD-TAMU-2009-05-541/MCPEEK DISSERTATION.pdf

[29] Peterson M. \& Tober B. (2017). "Institutionalizing the Vertical Studio: Curriculum, Pedagogy, and the Logistics of Core Classes with Mixed-Level Students". Available online: https//www. textimage.org/indices/pdf/Institutionalizing-the-Vertical-Studio.pdf

[30] Corazzo J. (2015). "Designing the Discipline: The Role of the Curriculum in Shaping Students' Conceptions of Graphic Design". Proceedings of the 3rd International Conference for Design Education Researchers. Vol. 1. 28-30 June 2015, Chicago, Il, USA.

[31] Betz J. A. (2004). "Peer Review Plus: A Case for Combining Architectural Design Studios Earlier". Available online: https//: www.peer.asee.org

[32] Delgado M. (2010). "Studio Culture: Teaching Design within the Studio Environment". 4th International Technology, Education and Development Conference. INTED2010 Proceedings. ISBN: 978-84-613-5538-9. Page: 271-276.

[33] Mcpeek K. T. \& Dockter B. (2008). "Extending the Mission of the Design Studio through Collaborative Engagement". Education for an Open Architecture. Ball State University, College of Architecture and Planning. p.85-90. Available online: https://www.irbnet.de/daten/iconda/CIB11017.pdf

[34] Teixeira M. B. F. (2005). "Collaboration in Design Studios”. MSc. Thesis. Istanbul Technical University. https://polen.itu.edu.tr/xmlui/bitstream/handle/11527/9531/2637.pdf?sequence=1\&isAllowed= $\mathrm{y}$ 